\title{
Performance of lactating dairy cows fed corn as whole plant silage and grain produced from genetically modified corn containing event DAS-59122-7 compared to a nontransgenic, near-isogenic control
}

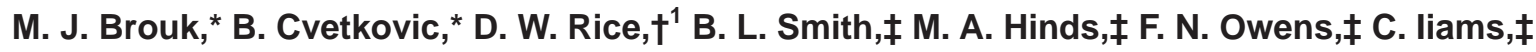 \\ and T. E. Sauber‡ \\ *Department of Animal Sciences and Industry, 134 Call Hall, Kansas State University, Manhattan 66506 \\ †Pioneer Hi-Bred Livestock Nutrition Center, 4780 NW 158th Ave., Polk City, IA 50226 \\ ¥Pioneer Hi-Bred, 7300 NW 62nd Ave., Johnston, IA 50131
}

\begin{abstract}
The nutritional equivalency of grain plus whole plant silage from genetically modified corn plants containing the DAS-59122-7 (59122) event expressing the Cry34Ab1 and Cry35Ab1 proteins to grain and silage from a near-isogenic corn hybrid without this trait (control) was assessed using lactating dairy cows. Corn plants with event 59122 are resistant to western corn rootworm and tolerant to the herbicide active ingredient glufosinate-ammonium. Effects on feed intake, milk production, and milk composition were determined. The 59122 grain and the control grain were produced in 2005 from isolated plots in Richland, Iowa. Whole plant corn silage for the 59122 and control treatments were grown in isolated plots at the Kansas State University Dairy Center and ensiled in Ag-Bags. Thirty lactating Holstein cows blocked by lactation number, day of lactation, and previous energy-corrected milk production were used in a switchback design. All cows were fed diets that contained $22.7 \%$ grain plus $21.3 \%$ whole plant silage from either the 59122 or the control hybrid, in addition to $21 \%$ wet corn gluten feed, $12.3 \%$ protein mix, $8.0 \%$ whole cottonseed, and $14.7 \%$ alfalfa hay. Each period of the switchback trial included 2 wk for diet adjustment followed by 4 wk for data and sample collection. Milk samples (a.m. and p.m.) collected from 2 consecutive milkings of each collection wk were analyzed for fat, protein, lactose, solids-not-fat, milk urea nitrogen, and somatic cell count. Percentages of milk fat, protein, lactose, and solids-not-fat were not affected by dietary treatment. Yields of milk, $4 \%$ fatcorrected milk, energy-corrected milk, solids-corrected milk, and the concentrations and yields of milk fat, milk protein, milk solids, and milk lactose were not significantly different between treatments. Efficiencies
\end{abstract}

Received May 26, 2010.

Accepted November 29, 2010

${ }^{1}$ Corresponding author: dave.rice@pioneer.com of milk, fat-corrected milk, energy-corrected milk, and solids-corrected milk production also were not different when cows were fed crops from 59122 than when they were fed the control hybrid. Milk production efficiency averaged 1.48 and $1.50 \mathrm{~kg} / \mathrm{kg}$ of dry matter intake for cows fed diets containing the control and 59122 corn, respectively. These data indicate that the nutritional value for milk production was not different between a diet containing grain plus whole plant corn silage produced from a 59122 corn hybrid versus a diet containing grain and corn silage from its near-isogenic control corn hybrid.

Key words: corn rootworm protection, corn hybrid, dairy cow

\section{INTRODUCTION}

Biotechnology is used to modify plants, animals, and microorganisms to enhance productivity, improve sustainability, and decrease the environmental footprint of agricultural production (Hartnell and Fuchs, 1999; Persley and Siedow, 1999). Corn is a major source of energy and forage fiber for dairy cattle in the United States. Efficiency of forage and grain production can be enhanced through biotechnology by providing plants with protection from insect pests and tolerance to herbicides used to reduce competition from weeds. $\mathrm{Nu}$ merous reports have tested the feeding value of crops altered by biotechnology (Donkin et al., 2003; Grant et al., 2003; Hartnell and Fuchs, 1999; Faust et al., 2007), both with lactating dairy cows and other farm animals. Feeding crops modified genetically with input (pesticide protection and herbicide resistance) traits has resulted in similar rates and efficiencies of production when compared with those of animals fed control diets formulated from isogenic nonmodified crops (Hartnell and Fuchs, 1999). In this study, we examined production responses of lactating cows fed grain and forage from plants containing the DAS-59122-7 event that expresses the Cry34Ab1 and Cry35Ab1 proteins versus 
those of cows fed grain and forage from a near-isogenic control hybrid without the DAS-59122-7 event. Corn plants with the 59122 event are resistant to western corn rootworm and tolerant to herbicides containing the active ingredient glufosinate-ammonium.

\section{MATERIALS AND METHODS}

\section{Corn Grain and Silage Sources}

Pioneer Hi-Bred, a DuPont Business (Johnston, IA) supplied the corn grain used in this study. Grain was produced in 2 fields isolated from each other and from other corn by a minimum distance of $201 \mathrm{~m}$ near Richland, IA. The 59122 grain was produced by corn plants that received 2 sequential applications of a glufosinate-ammonium herbicide (Liberty, Bayer Crop Science, Research Triangle Park, NC) to remove any corn plants that did not possess the herbicide tolerance trait. Spraying the control crop would have killed it. Grain from both fields was harvested, stored, ground finely (mean particle size of 700 microns) and delivered to the Kansas State University Dairy Unit (Manhattan, KS). Forage for the trial was grown in 2 isolated fields (separated by a minimum of $201 \mathrm{~m}$ ) near Manhattan. The 59122 forage came from plants that received 1 application of a glufosinate-ammonium herbicide (Liberty, Bayer Crop Science). Forages were harvested on August 17, 2005, by a custom harvester. All harvest equipment was cleaned with a pressure washer before chopping each hybrid to prevent cross-contamination. A self-propelled commercial harvester with a kernel processor was used to harvest forage at a theoretical cut length of $19 \mathrm{~mm}$. Forages were packed into separate Ag-Bags (Miller-St. Nazianz Inc., Co., St. Nazianz, WI) for ensiling and storage. Procedures to ensure identity preservation were followed throughout the trial for both grain and forage; ELISA analysis confirmed that Cry34Ab1 and Cry35Ab1 proteins were present in both the grain and forage from plants with the 59122 event, but were absent from control grain and forage (Pioneer Hi-Bred). Individual loads of forages were each sampled as Ag-Bags were filled and composite samples (2 per forage) were submitted to Cumberland Valley Analytical Services (Hagerstown, MD) for analysis; single samples of corn grains, fermented silages, hay, soybean meal, cottonseed, and wet corn gluten feed also were submitted for analysis. Analytical results were used for TMR formulation. The wet chemistry methods for concentration determination included moisture (AOAC, 2000; Goering and Van Soest, 1970); nitrogen (AOAC, 2000), using a Leco FP-528 nitrogen combustion analyzer (Leco, 3000 Lakeview Avenue, St. Joseph, MI); crude fat (AOAC, 2006); ADF (AOAC, 2000); NDF
Table 1. Ingredient composition of diets formulated with whole-plant corn silage plus corn grain from 59122 or control plants ${ }^{1}$

\begin{tabular}{lcc}
\hline & \multicolumn{2}{c}{ Diet } \\
\cline { 2 - 3 } $\begin{array}{l}\text { Ingredient, } \\
\text { \% of diet DM }\end{array}$ & Control & 59122 \\
\hline 59122 corn grain & 22.7 & 22.7 \\
Control corn grain & & \\
59122 corn silage & 21.3 & 21.3 \\
Control corn silage & 14.7 & 14.7 \\
Alfalfa hay & 8.0 & 8.0 \\
Whole cottonseed & 21.0 & 21.0 \\
Wet corn gluten feed $^{2}$ & 12.3 & 12.3 \\
${\text { Protein } \text { mix }^{3}}^{\text {Pyy }}$ & & \\
\hline
\end{tabular}

${ }^{1} 59122=$ corn plants containing the DAS-59122-7 event; control $=$ corn plants isogenic to 59122 but not containing the DAS-59122-7 event.

${ }^{2}$ SweetBran (Cargill Nutrition, Blair, NE).

${ }^{3}$ Contained percentages as fed: Soy Best (Soy Best-Grain States Soya Inc., West Point, NE), 67.10; fishmeal, 10.00; liquid molasses, 3.25; sodium bicarbonate, 5.50; magnesium oxide, 1.40; limestone, 9.25; trace mineralized salt, 2.30; vitamin A, D, E premix, 0.70; vitamin E premix, 0.12; sodium selenite premix, 0.01; Zinpro 4-plex (Zinpro Corporation, Eden Prairie, MN), 0.37.

and lignin (Goering and Van Soest, 1970); ash (AOAC, 2000); minerals (AOAC, 2000); starch (modification of Holm et. al., 1986, referenced by Hall, 2000); and sugar (DuBois, 1956).

\section{Cows, Feeding, and Milking}

The dietary treatments, animal care, and facilities were approved by the Kansas State University Institutional Animal Care and Use Committee (Protocol 2446) and were in accordance with guidelines recommended by FASS (1999). The experimental design was in accordance with International Life Sciences Institute (2003) guidelines, with an adequate number of replicate animals to detect a 5 to $10 \%$ difference between treatments at $P<0.05$ and a minimum power of $80 \%$ based upon the variance observed in a previous trial at this facility. Thirty lactating Holstein cows (second or greater parity), blocked by lactation number, DIM (average of 115 DIM), and ECM during the previous lactation, were assigned randomly to 1 of 2 dietary treatments (Table 1) in a single switchback design. Diets were formulated to supply adequate amounts of all nutrients and differed only by including silage plus grain from the hybrid with either the 59122 event or its near-isogenic control hybrid. Each period of the experiment lasted $6 \mathrm{wk}$ and included $2 \mathrm{wk}$ for diet adaptation, followed by $4 \mathrm{wk}$ for data and sample collection. Cows were injected at 14-d intervals throughout the study with recombinant bST (Posilac, Monsanto, St. Louis, MO). Housed in a tie-stall barn, cows had continuous access to feed and water and were milked twice daily in a double-5 herringbone milking parlor. Fresh feed was 
Table 2. Nutrient composition of corn grain and harvested whole plant corn at harvest and following fermentation ${ }^{1}$

\begin{tabular}{|c|c|c|c|c|c|c|}
\hline Item & \multicolumn{2}{|c|}{ Corn grain } & \multicolumn{2}{|c|}{ Fresh corn forage } & \multicolumn{2}{|c|}{ Fermented corn forage } \\
\hline DM, $\%$ & 88.5 & 87.7 & 33.7 & 34.8 & 35.8 & 34.8 \\
\hline Crude fat & 4.0 & 4.0 & 2.1 & 2.4 & 3.4 & 3.4 \\
\hline $\mathrm{ADF}$ & 4.1 & 4.6 & 24.9 & 22.0 & 23.6 & 25.0 \\
\hline $\mathrm{NDF}$ & 10.1 & 10.4 & 43.5 & 40.7 & 39.9 & 40.1 \\
\hline Potassium & 0.37 & 0.41 & 1.38 & 1.18 & 1.44 & 1.18 \\
\hline Lignin & & & 3.4 & 2.9 & 2.7 & 2.9 \\
\hline Starch & 68.1 & 66.5 & 25.4 & 28.9 & 26.5 & 28.0 \\
\hline Ash & 1.3 & 1.6 & 5.3 & 4.7 & 4.9 & 5.4 \\
\hline Soluble protein, $\%$ of $\mathrm{CP}$ & 27.3 & 26.6 & 39.8 & 40.7 & 58.2 & 58.1 \\
\hline
\end{tabular}

${ }^{1} 59122=$ corn plants containing the DAS-59122-7 event; control $=$ corn plants isogenic to 59122 but not containing the DAS-59122-7 event. Each value is the mean of analyses of replicated samples and is expressed as \% of DM, unless otherwise noted.

supplied twice daily as a TMR at 0600 and $1600 \mathrm{~h}$. The amount of TMR offered and refused was recorded daily for each animal; feed supply was adjusted daily to ensure that orts were about $10 \%$ of feed supplied to each animal. Samples of each TMR and individual feedstuffs (grains, silages, alfalfa hay, whole cottonseed, soybean meal, and wet corn gluten feed) were collected weekly and composited by period and diet. Samples of orts were obtained daily from each diet and composited by diet and period. All samples of feedstuffs and orts were submitted to Cumberland Valley Analytical Services for nutrient analysis as described earlier.

Cows were milked twice daily, at 0700 and $1700 \mathrm{~h}$ with individual milk weights being recorded. Milk samples (a.m. and p.m.) collected once each week from each cow were analyzed for protein, fat, lactose, SNF, MUN, and SCC at the Heart of America DHIA Laboratory (Manhattan, KS). Milk protein, fat and lactose concentrations were analyzed by near-infrared spectroscopy (Bentley 2000 Infrared Milk Analyzer, Bentley Instruments, Chaska, MN). A modified Berthelot reaction
(ChemSpec 150 Analyzer, Bentley Instruments) was used to determine MUN. Flow cytometry (Somacount 500, Bentley Instruments) was used to determine SCC. Mean milk composition for each week was calculated based on the proportion of milk produced each a.m. and p.m. and the composition of milk from each milking. Body condition scores were appraised visually (Wildman et al., 1982) at the start and end of each period; the change in BCS during each period was calculated by subtracting the ending BCS from the starting BCS. Body weights were determined on the final $2 \mathrm{~d}$ of wk $3,4,5$, and 6 immediately after the a.m. milking, with weights averaged for each cow by week. Body weight change during each period was calculated by subtracting the ending $\mathrm{BW}$ from the starting $\mathrm{BW}$.

\section{Statistical Analyses}

Two cows were removed from the study during the trial. One was removed due to a digestive disturbance unassociated with the study, and the second was re-

Table 3. Nutrient composition of analyzed TMR diets formulated with whole-plant corn silage and corn grain from 59122 or control plants, ${ }^{1}$ and analyzed diet refusals

\begin{tabular}{lccccc}
\hline & \multicolumn{3}{c}{ Diet } & & \multicolumn{2}{c}{ Diet refusals } \\
\cline { 2 - 3 } \cline { 5 - 6 } Item & Control & 59122 & & Control & 59122 \\
\hline DM, $\%$ & 62.1 & 62.0 & & 58.5 & 60.7 \\
CP & 20.1 & 19.4 & & 19.5 & 20.0 \\
ADF & 24.1 & 24.0 & & 25.4 & 23.9 \\
NDF & 37.7 & 38.4 & & 39.4 & 35.9 \\
Calcium & 0.74 & 0.81 & & 0.80 & 0.77 \\
Phosphorus & 0.59 & 0.58 & & 0.58 & 0.61 \\
Magnesium & 0.35 & 0.34 & & 0.35 & 0.37 \\
Potassium & 1.71 & 1.77 & & 1.76 & 1.62 \\
\hline
\end{tabular}

${ }^{1} 59122$ = corn plants containing the DAS-59122-7 event; control = corn plants isogenic to 59122 but not containing the DAS-59122-7 event. Each value is the mean of analyses of replicated samples and is expressed as $\%$ of DM, unless otherwise noted. 
moved due to mastitis. In both cases, all data from these 2 cows were removed before statistical analysis. Data from one additional cow were removed before statistical analysis due to a consistently depressed concentration of milk fat during both periods (mean of $2.17 \%$, more than $2 \mathrm{SD}$ below the trial mean). Removal of data for this cow from the data set did not alter the difference in milk fat values between the control and 59122 treatment groups, nor did it alter the treatment significance level. All intake and milk production data were averaged by week for each individual cow. Average weekly milk compositional data then were used to calculate the daily production of fat, protein, lactose, FCM, ECM, and SCM. Data from wk 1 and 2 of each period (adjustment time) also were removed before analysis. All data were subjected to analysis using PROC MIXED of SAS (SAS System for Windows, Release 9.3, SAS Inst. Inc., Cary, NC). The statistical model contained fixed effects of diet, week, and diet $\times$ week. Random effects included block, cow, period, and the interaction of cow $\times \operatorname{diet} \times$ period. Week within (cow $\times$ diet $\times$ period) was used as a repeated measure. Treatment means were computed using the LSMEANS option. Changes in BW and BCS also were analyzed using PROC MIXED of SAS (SAS System for Windows, Release 9.3, SAS Inst. Inc.) with a model that included diet as a fixed effect with random effects being block, cow, and period. Treatment means were computed using the LSMEANS option.

\section{RESULTS AND DISCUSSION}

Analyzed nutrient compositions of control and 59122 corn grain, fresh corn forage, and fermented corn forage (Table 2) were similar to values typical for corn grain and corn silage (Dairy One, 2010). Analysis of the fermented forages detected the presence of aflatoxin $(59122,7.4 \mu \mathrm{g} / \mathrm{kg}$; control, $8.6 \mu \mathrm{g} / \mathrm{kg})$, fumonisin (59122, $4.8 \mathrm{mg} / \mathrm{kg}$; control, $4.5 \mathrm{mg} / \mathrm{kg}$ ), zearalenone

Table 4. Milk production, milk components, efficiency of production, and body characteristics of cows fed diets containing corn silage and corn grain from 59122 or a control hybrid ${ }^{1}$

\begin{tabular}{|c|c|c|c|c|}
\hline \multirow[b]{2}{*}{ Item } & \multicolumn{2}{|c|}{ Diet } & \multirow[b]{2}{*}{$\mathrm{SE}^{2}$} & \multirow[b]{2}{*}{$P$-value } \\
\hline & Control & 59122 & & \\
\hline \multicolumn{5}{|c|}{ Production measures, $\mathrm{kg} / \mathrm{d}$} \\
\hline Milk & 43.6 & 43.2 & 0.6 & 0.58 \\
\hline DMI & 29.3 & 28.8 & 0.3 & 0.06 \\
\hline FCM & 40.7 & 39.9 & 0.7 & 0.26 \\
\hline $\mathrm{ECM}$ & 44.2 & 43.5 & 0.7 & 0.32 \\
\hline SCM & 48.0 & 47.4 & 0.7 & 0.35 \\
\hline \multicolumn{5}{|c|}{ Efficiency of production, $\mathrm{kg}$ of milk $/ \mathrm{kg}$ of feed } \\
\hline Milk & 1.48 & 1.50 & 0.02 & 0.28 \\
\hline FCM & 1.37 & 1.38 & 0.02 & 0.88 \\
\hline ECM & 1.49 & 1.50 & 0.02 & 0.66 \\
\hline SCM & 1.62 & 1.64 & 0.02 & 0.58 \\
\hline \multicolumn{5}{|c|}{ Milk component, $\%$} \\
\hline Protein & 3.18 & 3.20 & 0.02 & 0.35 \\
\hline $\mathrm{Fat}^{3}$ & 3.59 & 3.51 & 0.06 & 0.16 \\
\hline Lactose & 4.88 & 4.89 & 0.01 & 0.73 \\
\hline SNF & 9.01 & 9.04 & 0.03 & 0.31 \\
\hline \multicolumn{5}{|c|}{ Milk component yield, $\mathrm{kg} / \mathrm{d}$} \\
\hline Protein & 1.38 & 1.38 & 0.02 & 0.94 \\
\hline Fat & 1.56 & 1.52 & 0.04 & 0.21 \\
\hline Lactose & 2.13 & 2.11 & 0.03 & 0.62 \\
\hline SNF & 3.92 & 3.91 & 0.05 & 0.76 \\
\hline \multicolumn{5}{|l|}{ Other measure } \\
\hline MUN, mg/dL & 16.6 & 16.2 & 0.2 & 0.07 \\
\hline $\mathrm{SCC}, \times 1,000$ & 133 & 144 & 16 & 0.51 \\
\hline \multicolumn{5}{|l|}{ BW } \\
\hline Average, $\mathrm{kg}$ & 731.3 & 730.5 & 2.8 & 0.79 \\
\hline Change, kg & 14.0 & 15.2 & 3.5 & 0.73 \\
\hline \multicolumn{5}{|l|}{ BCS } \\
\hline Average & 2.80 & 2.80 & 0.10 & 0.93 \\
\hline Change & $0.12^{\mathrm{b}}$ & $0.26^{\mathrm{a}}$ & 0.06 & 0.03 \\
\hline
\end{tabular}

\footnotetext{
${ }^{\mathrm{a}, \mathrm{b}}$ Means within a row that do not share a superscript differ at $P<0.05$.

${ }^{1} 59122=$ corn plants containing the DAS-59122-7 event; control $=$ corn plants isogenic to 59122 but not containing the DAS-59122-7 event.

${ }^{2}$ Standard error of the difference between control and 59122 LSM.

${ }^{3}$ Milkfat values were 3.54 and $3.46 \%$ ( $\mathrm{SE}=0.06, P=0.16$ ) for control and 59122 groups, respectively, when data from the cow with consistently depressed milkfat were included in the data set.
} 
(59122, $632 \mu \mathrm{g} / \mathrm{kg}$; control, $648 \mu \mathrm{g} / \mathrm{kg}$ ), and vomitoxin (59122 and control, both $0.1 \mathrm{mg} / \mathrm{kg}$ ). Dietary concentrations of aflatoxin, fumonisin, and vomitoxin in the final mixed diets all fell below the limits specified by the FDA $(1994,2005)$ of $20 \mu \mathrm{g} / \mathrm{kg}, 15 \mathrm{mg} / \mathrm{kg}$, and 5 $\mathrm{mg} / \mathrm{kg}$, respectively. Diets and refusals from the diets were similar in nutrient composition (Table 3). This similarity indicates that the cows were not sorting their diets.

Production of milk and component-corrected milk were not affected by the source of the grain and forage included in the diet (Table 4). This matches previous reports indicating that production was not different when lactating dairy cows were fed grain plus silage from various genetically modified corn lines or from their isogenic control hybrids (Grant et al., 2003; Faust et al., 2007). The difference in DMI approached significance $(P=0.06)$, with cows fed the control diet consuming 1.7\% more DM than cows fed the 59122 $\operatorname{diet}(29.3$ vs. $28.8 \mathrm{~kg} / \mathrm{d})$. In studies published by others (Folmer et al., 2002, Grant et al., 2003; Ipharraguerre et al., 2003; Faust et al., 2007), DMI did not differ between animals fed modified versus control hybrids. Percentages of fat, protein, lactose, and SNF in milk were not significantly affected by treatment. The efficiency of production, the ratio of milk produced to feed consumed, also was not different. In addition, efficiencies of production of FCM and ECM did not differ with dietary treatment. Because cows fed the 59122 diet tended to consume less DM while producing similar amounts of milk and milk components, forage and grain from 59122 may have been digested more completely by the cows. Indeed, compositional data indicates that the 59122 forage (both fresh and fermented) had a slightly greater starch concentration than did the control forage. This also could explain why milk production rates could be similar despite a slightly lower DMI. The MUN concentration also tended to be slightly lower $(P$ $=0.07$ ) when cows were fed the $59122 \operatorname{diet}(16.6$ vs. $16.2 \mathrm{mg} / \mathrm{dL}$ ). However, all MUN concentrations were of a magnitude indicating that dietary $\mathrm{N}$ was adequate for efficient milk production. The slightly lower MUN concentration for cows fed crops with the 59122 event may reflect their slightly lower DMI and the slightly lower CP content of their diet. Temporal changes in BCS and BW both were positive, indicating that cows were in positive energy balance. Visually appraised BCS increased to a greater degree $(P<0.05)$ for cows fed the 59122 diet ( 0.26 vs. 0.12 ), again supporting the hypothesis that cows used the 59122 diet more efficiently than the control diet.

In summary, these data indicate that presence of the genetic modification (event DAS-59122-7) in corn plants did not alter the nutritional value of the grain plus silage, as measured by rate or efficiency of milk production and by milk composition of lactating dairy cows. Using genetic modification, efficiency of crop production can be improved through decreasing the adverse effects of insect and weed pests without any detectable effect on the productive performance of lactating dairy cows.

\section{REFERENCES}

AOAC. 2000. Official Methods of Analysis. 17th ed. Association of Official Analytical Chemists, Arlington, VA.

AOAC. 2006. Official Methods of Analysis. 18th ed. Association of Official Analytical Chemists, Arlington, VA.

Dairy One. 2010. Feed composition library. Accessed March 2010 http://www.dairyone.com/Forage/FeedComp.

Donkin, S. S., J. C. Velez, A. K. Totten, E. P. Stanisiewski, and G. F. Hartnell. 2003. Effects of feeding silage and grain from glyphosate-tolerant or insect-protected corn hybrids on feed intake, ruminal digestion, and milk production of dairy cattle. J. Dairy Sci. 86:1780-1788.

DuBois, M., K. A. Gilles, J. K. Hamilton, P. A. Rebers, and F. Smith. 1956. Colorimetric method for determination of sugars and related substances. Anal. Chem. 28:350-356.

FASS. 1999. Guide for the Care and Use of Agricultural Animals in Agricultural Research and Teaching. 1st rev. ed. Fed. Anim. Sci. Soc., Savoy, IL.

Faust, M., B. Smith, D. Rice, F. Owens, M. Hinds, G. Dana, and P. Hunst. 2007. Performance of lactating dairy cows fed silage and grain from a maize hybrid with the cry $1 \mathrm{~F}$ trait versus its nonbiotech counterpart. J. Dairy Sci. 90:5706-5713.

FDA. 1994. Compliance program guidance sec. 683.100: Action levels for aflatoxins in animal feeds. Accessed February 2010. http:// www.fda.gov/ICECI/ComplianceManuals/CompliancePolicy GuidanceManual/ucm074703.htm.

FDA. 2005. Compliance program guidance manual, program 7371.003: Feed contaminants program. Accessed February 2010. http:// www.fda.gov/downloads/AnimalVeterinary/GuidanceCompliance Enforcement/ComplianceEnforcement/ucm113409.pdf.

Folmer, J. D., R. J. Grant, C. T. Milton, and J. Beck. 2002. Utilization of Bt maize residues by grazing beef steers and Bt maize silage and grain by growing beef cattle and lactating dairy cows. J. Anim. Sci. 80:1352-1361.

Goering, H. K., and P. J. Van Soest. 1970. Forage fiber analysis. USDA Agricultural Research Service Handbook number 379. Agricultural Research Service, United States Department of Agriculture, Washington, DC.

Grant, R. J., K. C. Fanning, D. Kleinschmit, E. P. Stanisiewski, and G. F. Hartnell. 2003. Influence of glyphosate-tolerant (event nk603) and corn rootworm protected (event MON863) corn silage and grain on feed consumption and milk production in Holstein cattle. J. Dairy Sci. 86:1707-1715.

Hall, M. B. 2000. Neutral Detergent-Soluble Carbohydrates: Nutritional Relevance and Analysis. A Laboratory Manual. University of Florida Institute of Food and Agricultural Sciences Extension Bulletin 339, Gainesville.

Hartnell, G. F., and R. Fuchs. 1999. Current and future value of innovative technology in genetically modified grains and oilseeds. Pages 69-85 in Fifteenth Annual Carolina Swine Nutrition Conference, Carolina Feed Industry Assoc., Raleigh, NC.

Holm, J., I. Björck, A. Drews, and N.-G. Asp. 1986. A rapid method for the analysis of starch. Starch/Stärke 38:224-226.

International Life Sciences Institute. 2003. Best practices for the conduct of animal studies to evaluate crops genetically modified for input traits. Int. Life Sci. Inst., Washington, DC. 
Ipharraguerre, I. R., R. S. Younker, J. H. Clark, E. P. Stanisiewski, and G. F. Hartnell. 2003. Performance of lactating dairy cows fed corn as whole plant silage and grain produced from a glyphosatetolerant corn (event NK603). J. Dairy Sci. 86:1734-1741.

Persley, G. J., and J. N. Siedow. 1999. Applications of biotechnology to crops: Benefits and risks. CAST Issue Paper Number 12. Accessed
February 2010. http://www.cast-science.org/websiteUploads/publication PDFs/biotc_ip.pdf.

Wildman, E. E., G. M. Jones, P. E. Wagner, R. L. Boman, H. F. Troutt Jr., and T. N. Lesch. 1982. A dairy cow body condition scoring system and its relationship to selected production characteristics. J. Dairy Sci. 65:495-501. 